\title{
PROFIL PRIMIGRAVIDA MUDA DAN LUARAN PERSALINAN DI RUMAH SAKIT DR OEN SURAKARTA
}

\author{
Supanji Raharja ${ }^{1}$, Ova Emilia², Poedji Rochjati ${ }^{3}$
}

\begin{abstract}
Background: Pregnancy at a young age has become an important health problem both in developed and developing countries. Pregnancy at a young age increases the risk of maternal and perinatal morbidity and mortality. This is because adolescent women who are not ready both physically and psychologically to get pregnant.
\end{abstract}

Obsjective: This study aims to identify and analyze labor in young primigravida (<20 years) with pathological labor in hospital Dr.Oen Surakarta.

Method: This was an observational analytic study without intervention in the form of comparative cross sectional study conducted in young primigravida group age $<20$ years and primigravida group age 20 to 34 years old, who underwent labor in hospital delivery room. Dr.Oen Surakarta. This study used secondary data from the medical record of pregnant women who gave birth at RS.Dr.Oen Surakarta from January 1, 2011 to December 31, 201. A comparison between young primigravids ( $<20$ years) in which pathologic pathways were performed with primigravida of reproductive age (20-34 years) experienced pathological labor were conducted.

Result and Discussion: The number of deliveries in young primigravida ( $<20$ years) was 61 people (6.65\%) whereas in primigravida (21-35 years) there were 856 people (93.34\%). Younger primigravids have lower levels of education than the primigravida age of reproductive age ( $p 0.00, \mathrm{Cl} 3.557-11.227)$. The younger primigravida has a tendency to give birth outside its residence area compared to primigravida of reproductive age ( $\mathrm{p} 0.00 ; \mathrm{Cl} 0.050,178)$. Unmarried status in the young primigravida is greater than that of primigravida of reproductive age ( $\mathrm{p} 0.00, \mathrm{Cl} 0.011$ - 0,229). An Antenatal Care on Primigravida reproductive age is more regular than young primigravida ( $\mathrm{p} 0.03 ; \mathrm{Cl} 0.255-0.97)$. Young primigravida tended to have anemia ( $p=0.00$, OR $8.4 \mathrm{Cl} 3.22-21.93$ ) The risk of prematurity was higher in young primigravids than in the reproductive age primigravida ( 0.01 , OR $2.9 \mathrm{Cl} 1,16-7.25)$. Younger primigravids have a higher risk for pathologic delivery compared to primigravida of reproductive age ( $0.05 \mathrm{OR} 0.56 \mathrm{Cl} 0.315-1.01$ ). Conclusions: There are differences in terms, level of education, marital status, residence, regularity of ANC between young primigravida and prmigravida of reproductive age. The study found that young primigravids have a higher risk of occurrence of anemia, prematurity and pathologic delivery compared with healthy reproductive age primigravids.

Keywords: young primigravida, primigravida healthy reproductive age, risk factors

\section{ABSTRAK}

Latar Belakang: Kehamilan pada usia muda telah menjadi masalah kesehatan yang penting di banyak negara di dunia baik negara maju maupun negara berkembang. Kehamilan pada usia muda meningkatkan morbiditas dan mortalitas maternal dan perinatal. Hal ini disebabkan karena ibu hamil yang terlalu muda belum siap secara fisik ataupun psikis untuk hamil.

\footnotetext{
${ }^{1}$ RS dr. Oen Surakarta

${ }^{2}$ Departemen Obstetri dan Ginekologi, FKKMK UGM

${ }^{3}$ Departemen Obstetri dan Ginekologi, FK UNAIR
} 
Tujuan: Penelitian ini bertujuan untuk mengetahui dan menganalisis persalinan pada primigravida muda ( $<20$ tahun) dengan persalinan patologis di RS. Dr.Oen Surakarta.

Metode: Penelitian ini merupakan penelitian yang bersifat observasional analitik tanpa intervensi berupa studi comparative cross sectional yang dilakukan pada kelompok primigravida muda ( $<20$ tahun) dan kelompok perempuan primigravida usia 20 sampai 34 tahun, yang menjalani proses persalinan di kamar bersalin RS.Dr.Oen Surakarta. Pada Januari 2011 sampai Desember 2012. Penelitian ini menggunakan data sekunder dari rekam medik ibu hamil yang melahirkan di RS.Dr.Oen Surakarta mulai tanggal 1 Januari 2011 sampai dengan 31 Desember 2012 secara total sampling dengan mengacu kriteria yang disesuaikan dengan tujuan penelitian. Dilakukan perbandingan antara primigravida muda ( $<20$ tahun) yang mengalalmi proses persalinan patologis dengan primigravida usia reproduksi (20 - 34 tahun) yang mengalami proses persalinan patologis.

Hasil dan Pembahasan: Jumlah persalinan pada primigravida muda $(<20$ tahun) sebanyak 61 orang (6,65\%) sedangkan pada primigravida ( $21-35$ tahun) sebanyak 856 orang (93,34\%). Primigravida muda memiliki tingkat pendidikan yang lebih rendah dibanding golongan primigravida usia reproduksi ( $p$ 0,00 -; $\mathrm{Cl} 3,557-11,278)$. Primigravida muda memiliki kecenderungan untuk melahirkan diluar wilayah tempat tinggal nya dibandingkan dengan primigravida usia reproduksi ( $0.00 ; \mathrm{Cl} 0,050,178)$. Status tidak menikah pada primigravida muda lebih banyak dibandingkan dengan primigravida usia reproduksi ( 0,$00 ; \mathrm{Cl} 0,011$ - 0,229) . Ante Natal Care pada Primigravida usia reproduktif lebih teratur dibandingkan primigravida muda ( 0,$03 ; \mathrm{Cl} 0,255-0,97)$. Primigravida muda cenderung mengalami anemia ( $\mathrm{p} 0,00 ; \mathrm{OR} 8,4 \mathrm{Cl} 3,22$ - 21,93) Risiko terjadinya prematuritas lebih tinggi pada primigravida muda dibandingkan primigravida usia reproduksi optimal ( 0,$01 ; \mathrm{OR} \mathrm{2,9} \mathrm{Cl} 1,16-7,25$ ). Primigravida muda mempunyai risiko lebih tinggi untuk terjadinya persalinan patologis dibandingkan dengan primigravida usia reproduksi ( $\mathrm{p} 0.05$ OR 0,56 $\mathrm{Cl} 0,315-1,01)$.

Kesimpulan : Terdapat perbedaan dalam hal, tingkat pendidikan, status pernikahan, tempat tinggal, keteraturan ANC antara primigravida muda dan prmigravida usia reproduksi. Penelitian ini didapatkan primigravida muda memiliki risiko yang lebih tinggi untuk terjadinya anemia, prematuritas dan persalinan patologis dibandingkan dengan primigravida usia reproduktsi sehat.

Kata kunci : primigravida muda, primigravida usia reproduksi sehat, faktor risiko

\section{PENDAHULUAN}

Kehamilan pada usia muda merupakan salah satu masalah yang harus dihadapi oleh negara dan masyarakat di era globalisasi ini. Kehamilan pada usia muda di Indonesia masih cukup banyak, setiap tahun kira-kira 15 juta remaja berusia $15-$ 19 tahun melahirkan, 4 juta melakukan aborsi, dan hampir 100 juta terinfeksi penyakit menular seksual (PMS). Hal ini disebabkan majunya perkembangan bidang informasi dan tekhnologi sehingga anak-anak remaja mendapatkan informasi yang tidak tepat mengenai masalah seksologi dan kurang efektifnya penyaringan berita seputar masalah pronografi di dunia maya. Selain itu masih adanya kebiasaan untuk mengawinkan anak-anak wanita yang masih di bawah umur (20 tahun ke bawah). Ada beberapa alasan yang mendasari terjadinya hal ini antara lain faktor tuntutan untuk kawin muda dan hubungan seksual bebas, akses terhadap pendidikan dan pekerjaan, ketidaksetaraan gender, kekerasan seksual dan pengaruh media massa maupun gaya hidup yang bebas. Rata-rata usia kawin pertama yang rendah pada penduduk suatu daerah mencerminkan keadaan sosial ekonomi dan pendidikan yang rendah dari daerah 
tersebut. Perempuan dan laki-laki tidak banyak mempunyai alternatif kegiatan lain sehingga menikah muda dan meninggalkan bangku sekolah. ${ }^{1,2}$ Kehamilan remaja telah menjadi masalah kesehatan yang penting di banyak negara di dunia, baik negara maju maupun Negara yang sedang berkembang. Sebenarnya kehamilan remaja bukan merupakan fenomena baru, karena banyak masyarakat di Asia, Timur Tengah dan Afrika Utara yang menganut tradisi menikahkan anak pada usia remaja. Amerika, Polandia, Jerman, Kanada, Perancis, Jepang, Australia, Spanyol, Italia, Hungaria adalah 10 negara dengan angka kehamilan remaja yang tinggi di dunia. ${ }^{1,2}$

Amerika Serikat adalah negara maju dengan angka kehamilan remaja tertinggi di dunia. Namun, angka kehamilan remaja di Amerika Serikat dari 2007 sampai 2010 telah menurun drastis karena tingkat kesadaran remaja untuk melakukan konseling dini dan menggunakan kontrasepsi sejak usia seksual aktif semakin meningkat. Angka kelahiran hidup bayi dari ibu usia remaja di Amerika Serikat pada tahun 2010 adalah 409.840, dengan 50\% dari kehamilan tersebut adalah kehamilan yang tidak disengaja. ${ }^{3}$

Angka kejadian kehamilan remaja pada tahun 1998 per 1000 wanita usia 15-19 tahun rata-rata di Asia Selatan, Asia Timur dan Pasifik adalah 56, bervariasi dari 4 di Jepang dan 115 di Bangladesh. ${ }^{4}$ Angka kejadian kehamilan remaja di Indonesia menurut WHO adalah 58, tergolong tinggi dibandingkan 26 di Malaysia dan 40 di Filipina.Masyarakat Indonesia menghadapi kenyataan bahwa angka kejadian kehamilan pada usia remaja semakin meningkat dan telah menimbulkan masalah kesehatan, terutama kehamilan di bawah usia 20 tahun. Data Survei Demografi dan Kesehatan Indonesia tahun 2010 menunjukkan, sebanyak 9\% kelompok perempuan usia 15-19 tahun di Indonesia, pernah melahirkan bayi, berarti kurang lebih ada 100 orang per 1.000 perempuan. Jumlah tersebut cukup besar bila dibandingkan dengan Amerika yaitu 62 orang per 1.000 perempuan. $^{5}$

Hal yang menyebabkan tingginya kehamilan remaja juga dipengaruhi oleh angka unmet need akan kontrasepsi pada remaja yang belum menikah juga sangat tinggi, Hal ini disebabkan oleh sikap penolakan dari masyarakat, bertentangan dengan undang-undang setempat, klinik KB yang tidak melayani remaja yang belum menikah, sikap negatif terhadap alat/obat kontrasepsi oleh karena kurangnya informasi atau informasi yang salah, ketidaktahuan dimana tempat memperoleh alat kontrasepsi.

Di negara berkembang, hampir 60 persen kehamilan dan persalinan pada remaja yang sudah menikah atau belum menikah tidak dilakukan dengan persiapan dan pertolongan persalinan yang optimal. Persalinan yang tidak direncanakan dapat mengarah pada stress emosional dan kesulitan ekonomi. ${ }^{6}$

Banyak wanita yang kurang pengetahuan akan pentingnya informasi, akses prenatal, persalinan dan perawatan post partum sehingga bisa meningkatan resiko persalinan patologis yang pada akhirnya dilakukan persalinan dengan tindakan seperti seksio sesarea, ekstraksi vakum dan lain sebagainya. Risiko kehamilan pada ibu yang terlalu muda biasanya timbul karena mereka belum siap secara psikis maupun fisik. Secara psikis, umumnya remaja belum siap menjadi ibu. Pasalnya emosional ibu belum stabil dan ibu mudah tegang. Selain itu kondisi psikis yang tidak sehat ini dapat membuat kontraksi rahim selama proses persalinan tidak berjalan lancar seperti terjadinya kontraksi uterus yang lemah atau sifat kontraksi uterus yang berubah-ubah sehingga kemungkinan operasi sesarea jadi lebih besar. Risiko fisiknya pun tak kalah besar karena beberapa organ reproduksi remaja putri seperti rahim belum cukup matang untuk menanggung beban kehamilan. ${ }^{7}$ 
Persalinan patologis dan persalinan preterm bisa terjadi baik pada primigravida ataupun multigravida. Persalinan patologis dan persalinan preterm mempunyai dampak yang besar baik pada janin maupun pada ibunya. Kehamilan pada masa remaja berhubungan dengan meningkatnya risiko terhadap persalinan patologis dan luaran perinatal yang buruk seperti preeklamsi, berat lahir janin rendah dan prematuritas.1-3 .Anak yang lahir dari ibu remaja cenderung untuk memiliki berat badan lahir lebih rendah, cedera saat lahir, dan dihubungkan dengan komplikasi persalinan yang berdampak pada tingginya mortalitas. Peningkatan risiko kematian bayi pada ibu remaja juga dihubungkan dengan imaturitas kehamilan dan pengalaman minimal. Penelitian menunjukkan angka kematian bayi lebih tinggi pada bayi yang lahir dengan ibu remaja dibandingkan ibu berusia 20-30 tahun. ${ }^{8}$

Pada kenyataannya, kematangan seseorang banyak tergantung pada perkembangan emosi, latar belakang, pendidikan dan sosial. Perkembangan emosi yang tidakstabil merupakan penyebab kehamilan resiko tinggi terutama pada ibu usia muda, hal ini disebabkan ketidaksiapan mental menjadi seorang ibu. Upaya untuk mencegah resiko kehamilan dengan memberikan penjelasan tentang resiko kehamilan usia muda pada ibu, seperti memeriksakan kehamilan secara teratur selama masa kehamilan (sedikitnya empat kali kunjungan selama periode antenatal), makan makanan yang bergizi (peningkatan konsumsi makanan hingga 300 kalori per hari, mengkonsumsi makanan yang mengandung protein, zat besi, minum cukup cairan (menu seimbang). ${ }^{9}$

Kehamilan remaja masuk ke dalam kategori kehamilan risiko tinggi (risti) yang dapat meningkatkan angka mortalitas dan morbiditas pada ibu dan bayi. Untuk menunjang pencapaian MDGS 2014 dan 2015, yaitu menurunkan angka kematian ibu dan bayi, perlu dilakukan penelitian lebih lanjut mengenai komplikasi yang dapat timbul dari kehamilan remaja. ${ }^{10}$

\section{METODE}

Penelitian ini adalah analitik observasional dengan rancangan penelitian cross sectional, menggunakan pendekatan kuantitatif. Penelitian kuantitatif dilakukan untuk mengetahui perbedaan antara primigravida muda dengan primigravida usia reproduksi sehat, dalam hal tingkat pendidikan, tempat tinggal, status pernikahan riwayat ANC (Ante Natal Care), serta risiko terjadinya anemia, prematuritas dan proses persalinan patologis. ${ }^{11}$ Penelitian dilaksanakan di bagian kebidanan dan kandungan RS.Dr.Oen Surakarta. Waktu penelitian adalah mulai bulan Januari 2013 untuk mengumpulkan data mulai 1 Januari 2011 sampai dengan 31 Desember 2012.

\section{Kriteria kelayakan}

A. Kriteria inklusi adalah kriteria umum subyek dalam populasinya, yang diteliti yaitu:

a. Primigravida muda yaitu kehamilan anak pertama dengan usia $<20$ tahun

b. Primigravida usia reproduksi sehat: kehamilan anak pertama pada usia produktif ( $20 \leq 34$ tahun)

c. Ibu hamil primigravida dengan persalinan dengan tindakan (stimulasi persalinan, ekstraksi vakum, seksio sesarea)

B. Kriteria eksklusi adalah kriteria untuk mengeluarkan subyek yang telah memenuhi kriteria inklusi karena alasan tertentu seperti:

a. Ibu hamil primigravida muda dengan penyakit kronis (Asma, Penyakit jantung, Diabetis Melitus)

b. Kelainan bentuk dan besar janin (hidrosefalus,kembar siam, anensefalus)

c. Ibu hamil primigravida muda dengan data yang tidak lengkap.

C. Persalinan Patologis: Kelainan pada persalinan yang terdiri dari distosia karena kelainan his (power), distosia karena kelainan 
jalan lahir (passage), distosia karena kelainan janin (passenger), partus lama (prolonged labour) dan partus terlantar yang dalam penanganannya dilakukan persalinan buatan seperti:

a. Stimulasi persalinan adalah tindakan pada ibu hamil yang sudah inpartu baik secara operatif maupun medisinal, untuk merangsang timbulnya kontraksi rahim agar terjadi persalinan.

b. Ekstraksi vakum adalah suatu persalinan buatan di mana janin dilahirkan dengan ekstraksi tenaga negative (vakum) pada kepalanya.

c. Seksio sesarea suatu persalinan buatan di mana janin dilahirkan melalui suatu insisi pada dinding perut dan dinding rahim dengan sayatan rahim dalam keadaan utuh serta berat janin di atas 500 gram.

Populasi dan sampel penelitian

a. Populasi penelitian adalah ibu hamil primigravida yang melahirkan di RS.Dr.Oen Surakarta 1 Januari 2011 sampai dengan 31 Desember 2012.

b. Sampel

Sampel penelitian kuantitatif adalah seluruh primigravida yang memenuhi kriteria inklusi penelitian

\section{HASIL DAN PEMBAHASAN}

Jumlah persalinan di RS Dr Oen Surakarta pada tahun 2011 dan 2012 tercatat sebanyak 2368 persalinan. Dari jumlah tersebut terkumpul sebanyak 917 data yang memenuhi kriteria inklusi, dengan distribusi sebagai tersebut di tabel 1.
Tabel 1. Distribusi Subyek Penelitian

\begin{tabular}{crc}
\hline \multicolumn{1}{c}{ Primigravida } & Kasus & \multicolumn{1}{c}{$\%$} \\
\hline Primigravida muda (<20 tahun) & 61 & 6,65 \\
Primigravida (20-34 tahun) & 856 & 93,34 \\
\hline \multicolumn{1}{c}{ Jumlah } & 917 & 100 \\
\hline
\end{tabular}

Dalam kurun waktu ini, kasus primigravida (20 - 35 tahun) lebih dominan yaitu sebesar 93,34\% dibandingkan dengan kasus primigravida muda $(<20$ tahun) yang sebesar $6,65 \%$. Angka ini berbeda dengan hasil penelitian sebelumnya yang dilakukan di RS Moewardi Surakarta yang menunjukkan persentase sebanyak 9,7\% selama periode tahun 1 Januari 2003 sampai 31 Desember 2005.

Tabel 2. Distribusi Subyek Penelitian berdasarkan usia pada primigravida muda

\begin{tabular}{ccc}
\hline Usia (tahun) & Kasus & $\%$ \\
\hline 14 & 1 & 1,64 \\
15 & 1 & 1,64 \\
16 & 2 & 3,28 \\
17 & 8 & 13,11 \\
18 & 10 & 16,39 \\
19 & 39 & 63,93 \\
\hline Jumlah & 61 & 100 \\
\hline
\end{tabular}

Dari tabel 4.2 didapatkan data bahwa usia termuda adalah 14 tahun, dan persentasi terbanyak pada primigravida muda adalah pada golongan usia 19 tahun sebanyak 63,93\%. Sebagai perbandingan penelitian di salah satu negara berkembang yang dilakukan Boniface Uji Ago dan kawan-kawan di Calabar Nigeria tahun 2011, didapatkan usia termuda pada kehamilan remaja adalah pada usia 13 tahun sebanyak 1 kasus sedangkan untuk golongan terbanyak di usia 19 tahun yaitu 21 kasus $(25,6 \%) .{ }^{12}$ 
Tabel 3. Tingkat pendidikan pada primigravida muda dan primigravida usia reproduksi sehat

\begin{tabular}{|c|c|c|c|c|c|c|c|}
\hline \multirow{3}{*}{ Primigravida } & \multicolumn{4}{|c|}{ Pendidikan } & \multirow{3}{*}{$\mathbf{N}$} & \multirow{3}{*}{$\mathbf{p}$} & \multirow{3}{*}{$\mathrm{Cl} 95 \%$} \\
\hline & \multicolumn{2}{|c|}{ Rendah } & \multicolumn{2}{|c|}{ Tinggi } & & & \\
\hline & $\mathrm{n}$ & $\%$ & $\mathrm{n}$ & $\%$ & & & \\
\hline Muda & 22 & 36,1 & 39 & 63,9 & 61 & 0,00 & $3,557-11,278$ \\
\hline Usia reproduksi sehat & 70 & 8,2 & 786 & 91,8 & 856 & & \\
\hline
\end{tabular}

Tabel 4. Primigravida muda dan primigravida usia reproduksi sehat

\begin{tabular}{|c|c|c|c|c|c|c|c|c|}
\hline \multirow[t]{2}{*}{ Primigravida } & \multicolumn{2}{|c|}{ Muda } & \multicolumn{2}{|c|}{$\begin{array}{c}\text { Usia Reproduksi } \\
\text { sehat }\end{array}$} & \multirow[t]{2}{*}{$\mathbf{N}$} & \multirow[t]{2}{*}{$p$} & \multirow[t]{2}{*}{$\mathbf{R} \mathbf{R}$} & \multirow[t]{2}{*}{ Cl 95\% } \\
\hline & $\mathrm{n}$ & $\%$ & $n$ & $\%$ & & & & \\
\hline $\begin{array}{l}\text { Tempat tinggal } \\
\text { Dalam kota }\end{array}$ & 13 & 21,3 & 48 & 78,7 & 61 & 0,00 & 0,29 & $0,05-0,17$ \\
\hline Luar kota & 634 & 74,1 & 222 & 25,9 & 856 & & & \\
\hline Menikah & 57 & 93,4 & 4 & 6,6 & 61 & 0,00 & 0,94 & $0,011-0,229$ \\
\hline Tidak menikah & 853 & 99,6 & 3 & 4 & 856 & & & \\
\hline Anc Teratur & 49 & 80,3 & 12 & 19,7 & 61 & 0,03 & 0,90 & $0,255-0,970$ \\
\hline Anc Tidak teratur & 763 & 89,1 & 93 & 10,9 & 856 & & & \\
\hline Kadar HB Anemia & 7 & 11,5 & 54 & 88,5 & 61 & 0,00 & 7,77 & $3,22-21,93$ \\
\hline $\begin{array}{l}\text { Kadar HB Tidak } \\
\text { Anemia }\end{array}$ & 13 & 1,5 & 843 & 98,5 & 856 & & & \\
\hline Preterm & 6 & 9,8 & 55 & 90,6 & 61 & 0,01 & 2,72 & $1,16-7,25$ \\
\hline Aterm & 31 & 3,6 & 825 & 93,3 & 856 & & & \\
\hline Persalinan normal & 16 & 26,2 & 45 & 73,8 & 61 & 0,05 & 0,67 & $0,315-1,01$ \\
\hline Persalinan patologis & 330 & 38,6 & 526 & 61,4 & 856 & & & \\
\hline
\end{tabular}

Pada tabel 4 risiko terjadinya anemia pada kehamilan primigravida muda diuji secara statistik berdasarkan kadar Hemoglobin ( $\mathrm{Hb})$ untuk kelompok primigravida muda dan primigravida usia reproduksi. Odd Ratio dipakai sebagai indikator untuk menilai risiko terjadinya anemia pada primigravida muda. Hasil penelitian juga menunjukkan hamil primigravida muda dapat meningkatkan risiko terjadinya anemia sebesar hampir 8,4 kali (OR = 8,40, CI95\% = 3,22-21,93, $p=0,00)$. Risiko terjadinya persalinan prematur pada kehamilan primigravida muda diuji secara statistik berdasarkan usia kehamilan saat melahirkan berdasarkan hari pertama menstruasi terakhir untuk kelompok primigravida muda dan primigravida usia reproduksi sehat. Risk Ratio dipakai sebagai indikator untuk menilai risiko terjadinya prematuritas pada primigravida muda. Hasil penelitian menunjukkan bahwa terdapat perbedaan bermakna antara primigravida muda dan primigravida usia reproduksi sehat dalam hal prematuritas. Primigravida muda dapat meningkatkan risiko terjadinya prematuritas sebesar hampir 2,9 kali ( $R R=2,9, \mathrm{Cl} 95 \%=1,16$ 7,25, $p=0,01$ ) dibandingkan promugravida usia reproduksi sehat. 
Risiko terjadinya persalinan patologis pada kehamilan primigravida muda diuji secara statistik berdasarkan data yang diperoleh yang memenuhu kriteria inklusis yaitu proses persalinan secara pacuan, vakum extraksi maupun sectio seasaria. Odd Ratio dipakai sebagai indikator untuk menilai risiko terjadinya proses persalinan patologis pada primigravida muda.

Angka kejadian persalinan patologis pada primigravida muda sebanyak $45(73,8 \%)$ kasus sedangkan pada primigravida usia reproduksi sebanyak 526 (61,4\%) kasus dari perhitungan secara statistik tidak didapakan perbedaan bermakna walaupun primigravida muda memiliki risiko 0,56 kali untuk terjadinya persalinan patologis dibandingkan dengan primigravida usia reproduksi sehat.

Tabel 5. Analisis mulitivariat kadar $\mathrm{Hb}$, usia kehamilan dan proses persalinan dengan primigravida muda

\begin{tabular}{lrrr}
\hline \multicolumn{1}{c}{ Variabel } & B & $\boldsymbol{\beta}$ & $\boldsymbol{p}$ \\
\hline Anemia & 0,377 & 0,21 & 0,000 \\
Persalinan Preterm & $-0,093$ & $-0,74$ & 0,102 \\
\hline
\end{tabular}

Dari tabel 5 setelah dilakukan analisis multivariat didapatkan hasil bahwa anemia memiliki risiko yang paling tinggi pada primigravida muda dibandingkan dengan persalinan prematur.

\section{Kejadian persalinan pada primigravida muda.}

Pada beberapa dasawarsa terakhir, kehamilan remaja telah menjadi masalah kesehatan yang penting di sejumlah besar negara, baik di negara maju dan di negara berkembang. Peningkatan kehamilan remaja tentunya akan memicu peningkatan masalah kesehatan ibu dan anak. Permasalahan lain terkait kehamilan remaja antara lain adalah tingkat pendidkan ibu yang rendah, status pernikahan yang tidak jelas dan dampak sosial dari lingkungan sekitarnya yang menganggap bahwa kehamilan remaja merupakan aib sehingga memberikan dampak psikologis yang berat bagi ibu hamil tersebut. ${ }^{13}$

Banyak sekali alasan yang mendorong untuk terjadinya perkawinan dan kehamilan usia dini, seperti adanya kebiasaan faktor tuntutan untuk kawin muda dan hubungan seksual, akses terhadap pendidikan dan pekerjaan, ketidaksetaraan gender, kekerasan seksual dan pengaruh media massa maupun gaya hidup yang popular. Rata-rata usia kawin pertama yang rendah dari penduduk suatu daerah mencerminkan keadaan sosial ekonomi dan pendidikan yang rendah dari daerah tersebut. ${ }^{4}$

Untuk distribusi kehamilan pada usia remaja terbanyak adalah pada usia 19 tahun yaitu sebanyak 39 kasus $(63,93 \%)$ dan usia termuda yang hamil adalah di usia 14 tahun dengan jumlah satu kasus. Untuk kasus kehamilan di usia 14 tahun pada penelitian ini didapatkan data bahwa status saat hamil belum menikah dan masih sekolah di tingkat SMP. Domisili pasien berasal dari dalam kota, dengan riwatyat ANC yang tidak teratur. Proses persalinan pada usia kehamilan prematur, setelah persalinan terjadi komplikasi perdarahan post partum karena retensi sisa plasenta. Pada satu kasus kehamilan dengan usia 15 tahun memiliki karakteristik yang hampir sama, yaitu pasien saat hamil belum menikah dan masih sekolah di tingkat SMP dan berasal dari dalam kota dengan kejadian patologi persalinan yaitu persalinan prematur dengan didahului ketuban pecah dini dan terjadi komplikasi febris puerperalis. Dijumpai dua kasus primigravida muda dengan usia 16 tahun, satu kasus memiliki karakteristik yang sama dengan data untuk usia 14 dan 15 tahun dengan komplikasi yang berbeda yaitu adanya anemia. Sedangkan kasus yang lain tidak terdapat komplikasi persalinan, tetapi memiliki karakteristik yang sama yaitu status belum menikah dan masih sekolah di tingkat SMP. 
Dengan melihat hasil di atas maka diperlukan langkah antisipasi untuk mengatasi masalah kehamilan di usia yang sangat muda, yaitu pendidikan seks usia remaja pada tingkat SMP, baik untuk orang tua siswa maupun siswa, deteksi dini dan ANC rutin pada kasus kehamilan usia dini sehingga komplikasi kehamilan bisa dihindari.

\section{Perbedaan tingkat pendidikan, tempat tinggal, status pernikahan dan riwayat ANC antara primigravida muda dengan primigravida usia reproduksi sehat.}

Terdapat perbedaan tingkat pendidikan primigravida muda dengan primigravida usia reproduksi sehat. Dampak terjadinya kehamilan di usia remaja adalah kurangnya kesempatan bagi seorang ibu muda untuk dapat melanjutkan dan mencapai pendidikan yang lebih tinggi. Hal yang sama dijumpai pada penelitian yang dilakukan Indranil Dutta dan kawan-kawan di Rural medical College- Hospital Karnataka India tahun 2013, dimana didapatkan tingkat pendidikan primigravida muda yang rendah sebanyak 264 kasus $(53,6 \%)$ sedangkan pada primigravida usia reproduksi sehat sebanyak 44 kasus (8,9\%) . Dengan rendahnya tingkat pendidikan seorang ibu akan berdampak pada rendahnya kualitas ante natal care, yang pada akhirnya akan meningkatkan risiko luaran kehamilan yang buruk. ${ }^{13}$

Dari tabel 4 didapatkan hasil bahwa tempat tinggal asal golongan primigravida muda yang melahirkan di RS Dr.Oen Surakarta berbeda secara bermakna jika dibandingkan primigravida usia reproduksi sehat dimana, pada golongan primigravida muda banyak yang berasal dari luar kota. Hal ini dimungkinkan karena kehamilan di usia remaja diannggap sebuah hal yang kurang baik ataupun dianngap sebuah aib, sehingga tempat melahirkan dipilih yang lebih jauh dibandingkan domisili asal.
Terdapat perbedaan bermakna antara status tidak menikah pada primigravida muda dibandingkan dengan primigravida usia reproduksi sehat, dimana hal ini dapat dilihat dari tabel 4.

Dari tabel 4 didapatkan perbedaan yang bermakana antara ANC pada golongan primigravida muda dan primigravida usia reproduksi sehat. Keadaan ini menandakan masih rendahnya kesadaran tentang pentingnya melakukan kunjungan asuhan antenatal yang teratur di kelompok kehamilan remaja dibandingkan kelompok kehamilan usia reproduksi sehat. Gortzak-Uzan dan Chabra S juga mendapatkan hasil yang sama, persentase kunjungan asuhan antenatal terendah terdapat pada kelompok kehamilan remaja. ${ }^{14,15}$ Dari penelitian yang dilakukan Indranill Dutta dan kawan-kawan di Rural Medical College- Hospital Karnataka India tahun 2013, terdapat perbedaan yang cukup bermakna $(p<0,001)$ antara ante natal care yang tidak tercatat pada primigravida muda dengan primigravida usia reproduksi sehat. ${ }^{13} \mathrm{Ada}$ beberapa hal yang mendasari ketidak teraturan ANC pada primigravida muda, selain karena motivasi, kesadaran dari ibu hamil itu sendiri juga adanya perasaan malu dari seorang primigravida muda untuk mengontrol kan kehamilannya, Dukungan keluarga terutama suami serta sikap dari petugas kesehatan dalam hal ini bidan yang menganggap bahwa kehamilan pada usia muda merupakan sebuah aib. ${ }^{16}$

\section{Faktor-faktor risiko pada primigravida muda .}

Dari tabel 4 didapatkan hasil bahwa risiko kejadian anemia pada kehamilan lebih tinggi pada golongan primigravida muda dibandingkan pada golongan primigravida usia reproduksi sehat hal ini menandakan kurangnya kualitas ANC dan langkah-langkah yang dilakukan ibu hamil dalam mencegah anemia misalkan kurang tercukupinya asupan tablet tambah darah serta diet yang 
kurang bergizi. Pada penelitian Indranil Dutta dan kawan- kawan di Rural Medical College- Hospital Karnataka India tahun 2013, anemia merupakan komplikasi yang cukup tinggi sebanyak $68,4 \%$ pada primigravida jika dibandingkan primigravida usia reproduksi sehat $33,32 \%$. Terdapat hubungan yang signifikan $(p<0,001)$ antara rata - rata kadar $\mathrm{Hb}$ dengan usia ibu hamil pada primigravida dimana semakin muda usia ibu semakin rendah kadar $\mathrm{Hb}$ nya. Berdasarkan data BKKBN Propinsi Sumatera Utara pada tahun 2007 rata-rata usia kawin pertama adalah 19,8 tahun dan diharapkan pada tahun 2014 rata-rata usia kawin pertama menjadi 20 tahun. Dengan rata-rata usia perkawinan di bawah usia 20 tahun maka akan berdampak pada kehamilan karena organ reproduksi belum matang sehingga dapat menimbulkan risiko anemia pada kehamilan remaja. ${ }^{13}$

Kehamilan pada masa remaja mempunyai risiko medis yang cukup tinggi, karena pada masa remaja alat reproduksi belum cukup matang untuk melakukan fungsinya. uterus akan siap melakukan fungsinya setelah wanita berumur 20 tahun, karena pada usia ini fungsi hormonal akan bekerja maksimal. Pada usia 15-19 tahun, sistem hormonal belum stabil. Dengan sistem hormonal yang belum stabil maka proses kehamilan menjadi tidak stabil, mudah terjadi anemia, perdarahan,abortus atau kematian janin. Pengaruh anemia kehamilan khususnya pada usia remaja dapat menyebabkan bahaya selama hamil seperti terjadi abortus, persalinan prematuritas, hambatan tumbuh kembang janin dalam rahim, mudah terjadi infeksi, perdarahan, hiperemesis, ketuban pecah dini dan bahaya saat persalinan yaitu gangguan his (kekuatan mengejan), kala pertama berlangsung lama, terjadi partus terlantar, perdarahan post partum, atonia uteri. Bahaya pada masa nifas yaitu terjadi subinvolusi uteri, menimbulkan perdarahan postpartum, memudahkan infeksi postpartum, pengeluaran ASI berkurang. Sedangkan bahaya anemia terhadap janin yaitu dapat terjadi abortus, kematian intrauterine, persalinan prematuritas tinggi, BBLR, kelahiran dengan anemia, dapat terjadi cacat bawaan, intelegensia rendah. ${ }^{17}$

Tabel 4 di atas menunjukkan bahwa hamil primigravida muda dapat meningkatkan risiko terjadinya prematuritas sebesar hampir 2,9 kali. Sedangkan pada penelitian yang dilakukan di Rural Medical College- Hospital Karnataka India tahun 2013, oleh Indranil Dutta, Kumar Dutta dan Prashant Joshi riskio terjadinya prematuritas pada primigravida muda sebanyak 4 kali jika dibandingkan pada primigravida usia reproduksi. ${ }^{13}$ Pada studi yang dilakukan Bhaduria, Bhattacharya dan Shravage JC didapatkan insiden prematuritas yang lebih tinggi pada primigravida muda yang berhubungan dengan tingginya kasus preeklampsi dan anemia pada primigravida muda. Kejadian prematuritas pada primigravida muda, dipicu oleh faktor psiko-sosial dimana sering terjadinya kecemasaan, depresi dan stress pada seorang primigravida muda. ${ }^{18}$ Stres pada ibu hamil dapat meningkatkan kadar katekolamin dan kortisol yang akan mengaktifkan placental corticotropin releasing hormone dan mempresipitasi persalinan melalui jalur biologis. Stres juga mengganggu fungsi imunitas yang dapat menyebabkan reaksi inflamasi atau infeksi intraamnion dan akhirnya merangsang proses persalinan. Moutquin, membuktikan bahwa stress yang berhubungan dengan kejadian prematuritas adalah adanya peristiwa kematian, keluarga yang sakit, kekerasan dalam rumah tangga, atau masalah keuangan. ${ }^{19}$

Terdapat beberapa faktor yang diketahui sebagai etiologi terjadinya proses persalinan patologis dan persalinan preterm diantaranya faktor kelainan pada janin serta faktor maternal. Faktor maternal pastinya sangat berpengaruh pada keberhasilan proses persalinan dan 
kejadian persalinan prematur . Adanya beberapa alasan meningkatnya persalinan patologis dan persalinan preterm yaitu tentang kurangnya pengetahuan akan pentingnya informasi, akses prenatal, persalinan, sehingga bisa meningkatkan risiko persalinan patologis yang pada akhirnya dilakukan tindakan seperti seksio sesarea, ekstraksi vakum dan lain sebagainya. Adanya risiko kehamilan pada ibu yang terlalu muda juga bisa menyebabkan persalinan patologis dan persalinan preterm, biasanya timbul karena mereka belum siap secara psikis maupun fisik. Secara psikis, umumnya remaja belum siap menjadi ibu. Pasalnya emosional ibu belum stabil dan ibu mudah tegang. Selain itu kondisi psikis yang tidak sehat ini dapat membuat kontraksi rahim selama proses persalinan tidak berjalan lancar seperti terjadinya kontraksi uterus yang lemah atau sifat kontraksi uterus yang berubahubah sehingga kemungkinan operasi sesarea jadi lebih besar. Risiko fisiknya pun tak kalah besar karena beberapa organ reproduksi remaja putri seperti rahim belum cukup matang. ${ }^{20,21}$

Pada table 4 dapat dilihat bahwa persentase persalinan patologis pada primigravida muda $(<$ 20 tahun) sebanyak 73,8 \% dari seluruh proses persalinan pada kelompok primigravida muda. Angka ini berbeda dengan hasil pada penelitian sebelumnya yang dilakukan di RS Mooewardi Surakarta sebanyak 53,1 \% selama periode tahun 1 Januari 2003 sampai 31 Desember 2005. Sedangkan pada persentase persalinan patologis pada primigravida (21-<34 tahun) sebanyak $61,4 \%$, angka ini berbeda dengan persentase pada penelitian sebelumnya di RS Moewardi Surakarta sebesar $56 \%$. Kehamilan pada usia reproduktif memiliki kesiapan mental untuk melahirkan secara alami dan sudah berencana tentang bayi dan kandungan secara matang, keadaan ekonomi mereka umumnya sudah siap untuk membiayai kehamilan dan bayi dan adanya pengetahuan yang luas tentang kepentingan gizi dan kesehatan bayi juga sudah mereka miliki. ${ }^{9}$ Perbedaan yang bermakna juga didapatkan dari penelitian yang dilakukan Indranil Duta dan kawan-kawan di Rural Medical College- Hospital Karnataka India tahun 2013, untuk kejadian gawat janin, preeklampsi yang juga berdampak terhadap tingginya angka persalinan dengan seksio sesarea antara primigravida muda dengan primigravida usia reproduksi. ${ }^{13}$

\section{KESIMPULAN DAN SARAN}

\section{Kesimpulan}

Primigravida muda memiliki tingkat pendidikan yang lebih rendah dibanding golongan primigravida usia reproduksi sehat serta memiliki kecenderungan untuk melahirkan diluar wilayah tempat tinggalnya dibandingkan dengan primigravida usia reproduksi sehat. Terdapat perbedaan bermakna status tidak menikah antara primigravida muda dan usia reproduksi sehat.Ante Natal Care pada Primigravida usia reproduksi sehat lebih teratur dibandingkan primigravida muda. Selain itu primigravida muda mempunyai risiko yang lebih tinggi mengalami anemia, prematuritas sedangkan persalinan patologis tidak ada perbedaan yang bermakna.

\section{Saran}

Pencegahan persalinan maupun kehamilan pada usia kurang dari 20 tahun, dilakukan dengan meningkatkan pendidikan dan pengetahuan tentang risiko kehamilan usia muda, terutama memudahkan komunikasi, informasi, edukasi, dan motivasi (KIEM) kepada masyarakat. Melakukan pencatatan terhadap temuan dan melakukan Ante Natal Care yang terarah, berkala dan teratur pada kasus primigravida muda. Dengan adanya keterbatasan pada penelitian ini, maka diharapkan supaya bisa dilanjutkan pengembangan untuk penelitian lain dengan memperhatikan faktor-faktor lain yang dapat 
mempengaruhi persalinan patologis seperti, pendidikan ibu, keadaan sosial ekonomi dan lain sebagainya.

\section{DAFTAR PUSTAKA}

1. Hartono A, Gunanegara F. R, Ivone J. 2012. Perbandingan Risiko Komplikasi pada Ibu dan Bayi pada Kehamilan Remaja dan Usia Reproduksi Sehat di Rumah Sakit Immanuel Bandung Periode Mei 2009 - Mei 2012 , Tesis Fakultas Kedokteran, Universitas Kristen Maranatha, Bandung.

2. Sastrawinata S, U. 2007. Gambaran Epidemiologi Klinik Kehamilan Remaja di RS Immanuel Bandung. Jurnal Kesehatan Maranatha . Vol.7 No.1 Juli 2007: 70-84

3. Hasan M, Silvana M. 2012. Kehamilan Remaja Di Amerika Serikat: Penyebab, Dampak Dan Upaya Pencegahannya, Tesis Program Studi Pengkajian Amerika, Fakultas IImu Budaya Universitas Gajah Mada Jogjakarta.

4. Acharya DR, Bhattarai R, Poobalan A, van Teijlingen E R, Chapman G.2010. Factors Associated with Teenage Pregnancy in South Asia: a systematic review. Health Science Journal, Vol $4: 3-14$

5. Destiara S. 2011. Perbandingan Luaran Maternal dan Perinatal Kehamilan Trimester Ketiga antara Usia Muda dan Usia Reproduksi Sehat, Karya Tulis Ilmiah Fakultas Kedokteran Universitas Diponegoro, hal:1-29

6. Singh, S, D, J.E. 2000. Adolescent Pregnancy and Childbearing: Level and Trends In Developed Countries. Family Planning Perspective, hal: 14-23.

7. Kurniawati, A. 2009. Hubungan Antara Primigravida Muda Dengan angka Kejadian Preeklamsia/ Eklamsia di RSUD Dr. Moewardi Surakarta Periode 1 Januari-31 Desember 2008. Universitas Muhammadiyah Surakarta. Solo.

8. Olausson O P, Cnattingius S, Haglund B. 1999. Teenage pregnancies and risk of late fetal death and infant mortality. British Journal of Obstetrics and Gynaecology February 1999, 106: 116-121

9. Sukmawati, M. 2006. Hubungan Antara Persalinan Patologis dengan Primigravida Muda di RSUD Dr. Moewardi Surakarta. Universitas Sebelas Maret. Solo.
10. Adjie S JM, et all, Kehamilan Remaja. Dalam: Ocviyanti D, Editor.2013. Upaya Meningkatkan Kualitas Pelayanan Kesehatan Reproduksi untuk Mencapai Millenium Development Goals 2015, Monograf PIT HOGSI 2013

11. Pratiknya, W.A. 2000. Dasar-dasar Metodologi Penelitian Kedokteran dan Kesehatan. Raja Grafindo Persada. Jakarta, 2000:10-21

12. Ago U B, Abeshi S, Njoku C, Agan U T, Ekabua J.2013. Obstetric Outcome of Booked Teenage Pregnavies at University of Calabar Teaching Hospital, Nigeria. Adolescent Health, Medicine and Therapeutics 2013:3 105-109

13. Dutta I, Dutta K D, Joshi P. 2013. Outcome of Teenage Oregnancy in Rural India wity Particular Reference to Obstetrica; Risk Factor and Perinatal Outcome, Journal of South Asian federation of Obstetrics and Gynecology, September-Desember 2013;5(3):102106

14. Gortzak-Uzan L, Hallak M, Press F, Teenage pregnancy : risk factors for adverse perinatal outcome, J Matern Fet Med, 2001; 10:393-7

15. Chabra S, Perinatal outcome in teenage mother, I J Obstet Gynecol 1991;41:30-2

16. Aryastami K N, Tarugan U. 2012. Perilaku Ibu Hamil dalam Memeriksakan kehamilan Trimester pertama di Puskesmas Pesanggrahan Jakarta Selatan, Buletin Penelitian Sistem Kesehatan, Vol 15 No. 1 Januari 2012: 11-19

17. Manuaba IBG. 2002. Konsep Obstetri \& Ginekologi Sosial Indonesia. Ed 1. EGC. Jakarta. hal: 76-95

18. Bhaduria, Bhattacharya dan Shravage JC. 1991. Teenage pregnancy: a retrospective study. J.Obstet Gynae India, 1991; 41:454-456.

19. Moutquin, JM. 2001. Socio Economic and Psychosocial Factor in the Management and Prevention of Preterm Labour. Br. J Obstet Gynaecol 2001; 20: 56-60

20. Widjayanegara H. 2009. Aspek Umum Prematuritas. Dalam : Krishnadi R, Sofie editor. Prematuritas. Bandung, 2009: 1-6

21. Verralls Sylvia. 1997. Anatomi dan Fisiologi Terapan dalam Kebidanan; alih bahasa, Hartono, Ed 3, Jakarta : EGC, hal: 56-76 